\title{
RITKA MADÁRFAJOK MEGFIGYELÉSEI AZ ÉSZAK-HANSÁG VIDÉKÉN
}

\author{
Balsay Sándor \\ 9241 Jánossomorja, Vadász tér 9.
}

\begin{abstract}
BALSAY S.: OBSERVATIONS OF RARE BIRD SPECIES IN NORTHERN-HANSÁG. Hungarian Small Game Bulletin 12: 151-154. http://dx.doi.org/10.17243/mavk.2014.151

Author presents his faunistical observations on rare bird species in Northern-Hanság (NW-Hungary) in the period between 1975 and 1993. The strictly protected or threatened species are the followings: Black Stork (Ciconia nigra), Black Kite (Milvus migrans), White-tailed Eagle (Haliaeetus albicilla), Red-footed Falcon (Falco vespertinus), Snowy Owl (Bubo scandiacus), Black Woodpecker (Dryocopos martius), Roller (Coracias garrulus), Dunnock (Prunella modularis) and Lesser Grey Shrike (Lanius minor).
\end{abstract}

KULCSSZAVAK: ritka madárfajok, faunisztikai adatok, Észak-Hanság KEY WORDS: rare bird species, faunistical data, Northern-Hanság

\section{BEVEZETÉS}

Jelen közlésemben elsősorban az Észak-Hanság területén, 1975-1993 között végzett, e területen ritkább, vagy természetvédelmi szempontból általában kiemelt fontosságú madárfajokra vonatkozó megfigyeléseimet teszem közzé.

\section{RÉSZLETES MEGFIGYELÉSEK}

\section{FEKETE Gólya (Ciconia nigra)}

Az 1976-os megjelenése nagy feltünést keltett, bár az általunk kevésbé látogatott, nevezetes Figurákban már költhetett korábban is. Fokozatosan terjedt el az Észak-Hanságban és legalább 7 fészekhelyét ismertük, ebből évente 5-6 fészek volt lakott.

1976.04.17. $2 \mathrm{pd}$

04.25. $4 \mathrm{pd}$

05.26 .

06.26 .

08.06. 2 pd juv

08.08. $1 \mathrm{pd}$

1977.06.30. $1 \mathrm{pd}$ ad.

08.24. $1 \mathrm{pd}$

1979.06.29. 2 pd juv

1981.08.10. 2 ad és 3 juv

1985.04.06. $2 \mathrm{pd}$ 04.10. $1 \mathrm{pd}$
Vesszőserdő és Dombosházi rét felett köröztek

keringtek az előbbi rét felett

megtaláltuk az első bizonyító fészkét a közelben

a fészek ellenőrzésekor 2 pd fióka volt a fészekben

tartózkodott a fészek közeli csatornában

Császárrét-gulyaállási csatornában (ez már egy másik fészekhez tartozhatott)

a Bordacsi-csatornában tartózkodott

a Bordacsi-csatorna felett repült

a dombosházi fészekben

körözött a Hanságfalva, Madárerdő felett (lehettek dél-hanságiak is)

a Dombosházi erdő felett köröztek

a Dombosházi erdő felé repült 
04.21. $1 \mathrm{pd} \quad$ a Dombosház melletti csatornából repült fel

1986.07.13. $1 \mathrm{pd}$

1987.04.09. $1 \mathrm{pd}$

1988.04.21. $1 \mathrm{pd}$

1989.05.25. $1 \mathrm{pd}$

05.27. $2 \mathrm{pd}$

07.09. $1 \mathrm{pd}$

08.23. $1 \mathrm{pd}$

1991.07.07. $1 \mathrm{pd}$

1992.07.29. $1 \mathrm{pd}$
Krisztinaberek, Oldalégés (keleti oldal) felett repült

Császárrét, Gulyaállási csatornából repült fel

Lébény, Töllösi erdőbe szállt be

Császárrét, Gulyaállási csatornában tartózkodott

Vesszőserdő, Dombosháznál repültek

Vesszőserdő melletti réten

Bordacsi-csatorna közelében repült

Hanságfalva-somorjai erdőben egy csatornában táplálkozott

Vesszőserdő felett repült

\section{BARNA KÁNYA (Milvus migrans)}

Költését nem tapasztaltuk, de költési időben is többször láttuk a környéken.

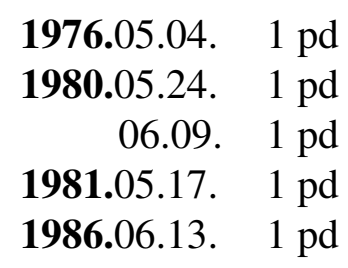

Vesszőserdő (Kimle) mellett

az Olajkúti út felett vadászott

a 86-os út császárréti szakasza mellett láttam repülni

Rohrerföldi recetábla felett vadászott

a 86-os út császárréti szakasza mellet láttam

\section{RÉTI SAS (Haliaeetus albicilla)}

A legnagyobb ragadozó madarunk hansági megjelenése az 1970-es évek közepén történt, először fiatal, kóborló példányokkal. Az első fészkelését a lébényi Figurákban észleltük 1984ben.

1975.05.11. 1 pd juv.

11.23. 1 pd juv.

11.24. 2 pd juv.

1977.12.18. $1 \mathrm{pd}$

1981.05.10. $1 \mathrm{pd}$ ad.

1984.12.02. $3 \mathrm{pd}$

1985.01.12. $3 \mathrm{pd}$

1986.02.03. $1 \mathrm{pd}$ ad.

1987.02.02. $2 \mathrm{pd}$ ad. 03.05. $1 \mathrm{pd}$

1988.01.15. $1 \mathrm{pd}$ 02.07. $1 \mathrm{pd}$

12.08. $1 \mathrm{pd}$ ad.

12.22. $1 \mathrm{pd}$ ad.

12.23. $2 \mathrm{pd}$

1990.07.16. 1 pd juv.

1992.01.18. $1 \mathrm{pd}$ ad.

02.25. $1 \mathrm{pd}$

1993.06.05. 1 pd juv. lébényi Figurák felett repült

Jánosi legelö fölött repült (FARAGÓ SÁNDORral láttuk)

Tóbi liget, földről repültek fel

Tóbi liget

Hanság-csatorna felett repült

hanságfalvai nemesnyarasba repült be éjszakázni

az előző helyen láttuk ismét, 2 pd ad. és 1pd juv.

86-os út felett a Szőke tónál repült keleti irányba

Hanság-csatorna mellett, a Madárerdőnél láttunk telelő példányokat

Hanságfalva közelében keringett

Hanságfalva mellett repült nyugati irányba

Jánossomorjától északnyugatra, a Rohrerföldnél szállt be egy facsoportba

Kápolna tanya közelében, lucerna tarlón

Madárerdőnél repült

Madárerdőnél keringett

Péteri legelőnél a lucernán valamit fogyasztott

Somorjai erdő, országhatár melletti nyárasába repült be

Somorjai erdők felett repült

Kápolna tanya közelében, lucerna táblán. 
KÉK VÉRCSE (Falco vespertinus)

Elsősorban a Mosonszolnok és Hegyeshalom közti területen lehetett látni költési időben. Táplálékszerzés közben megjelent Jánossomorja térségében is.

1979.08.11. cca. 20 pd a Péteri legelőnél, búzatarlón, egész nap

08.20. $2 \mathrm{pd} \quad$ a Péteri legelőnél vadászott

1980.07.26. 2-3 pd Frank dülőben repült a gabona tarló felett

1984.05 .

Irénmajor melletti fasorban több héten keresztül figyeltem egy fészek életét, benne 4 fiókával

1987.05.24.

05.11. $1 \mathrm{pd}$

Irénmajornál, egy másik fészek körüli veszekedést figyeltem meg

Jánossomorja alatt, a Szőke tónál vadászott

1989.06.04. $4 \mathrm{pd}$

06.18. $6 \mathrm{pd}$

Mosonszolnoki lucerna feletti villanyvezetéken,

06.21. $3 \mathrm{pd}$

az előbbi helyen, a vezetéken

07.07. $7 \mathrm{pd}$

az előbbi helyen láttam ismét

az előző helyen, a tábla tárcsázása idején a vezetékről figyelt.

1990.06.05. $40-50 \mathrm{pd}$

a Péteri legelőn, lucerna kaszálás közben.

HóBagoly (Bubo scandiacus)

1987.04.20.

1 pd juv. Lébény, Töllösi nemes nyáras tuskózott területén (2 erdőmérnök kollégával együtt figyeltük cca. 150 méterröl, majd alacsonyan elrepült)

1993.02.09. 1 pd juv. Az előző megfigyelés helyszínén láttuk dr. KÖHALMY

TAMÁs társaságában.

FEKETE HARKÁLY (Dryocopus martius)

1974 körül észleltük az első példányok megjelenését a keleti részeken, a Vesszős erdőben, azóta elterjedt az egész Észak-Hanságban. Még nemes nyarasokban is fészkel.

1974.12.12. $1 \mathrm{pd}$

12.27. $2 \mathrm{pd}$

1975.02.02. $1 \mathrm{pd}$

09.29. $1 \mathrm{pd}$

1976.06.11. $1 \mathrm{pd}$

1979.11.14. $1 \mathrm{pd}$

1981.05.21. $1 \mathrm{pd}$

1985.07.29. $1 \mathrm{pd}$

1986.05.04. $1 \mathrm{pd}$

1987.08.27. $1 \mathrm{pd}$

1988.07.21. $1 \mathrm{pd}$

1992.01.24. $1 \mathrm{pd}$

02.02. $1 \mathrm{pd}$
Császárrét, Gulyaállási erdőben.

Vesszőserdőben

Hanság, Nagyerdőben láttam repülni

Krisztina bereknél láttam repülni.

Hanságfalva, Jancsi-majori erdőnél

Rábca hullámterében, Tárnokrétinél

Császárrét, Gulyaállási erdőben láttam

Hanság, Nagyerdői tölgyesben hallottam hangját

Hanságfalva, Somorjai erdő felett láttam repülni

Császárrét, Populétumnál láttam repülni

Hanságfalva, Somorjai erdőben

Császárrét, Gulyaállási erdő

Császárrét, Gulyaállási erdő. 


\section{SzalaKóta (Coracias garrulus)}

A Hanság egyik ékessége eltünt a vidékről. 1986 után már mások sem látták a környéken.

1976.07.27. $5 \mathrm{pd}$ Hanságligettől keletre, valószínủleg egy család lehetett a Rábca partról

1977.06.24. $3 \mathrm{pd}$ Rábca töltésen Tárnokréti térségében egymástól távolabb 1980.06.16. $3-4 \mathrm{pd}$ Rábca töltésen, a hullámtérben fészkelő példányok közül 1986.07.19. $1 \mathrm{pd}$ Rábcakapira vezető út melletti villanyvezetéken ült

\section{KIS ŐRGÉBICS (Lanius minor)}

Mint érdekes, vonuló madár a térségben mindenhol előfordult a megfigyelések szerint, de a fészkelési időben csak a Hanságon kívül találtam. A Mosoni-síkon a kék vércsékkel együtt mutatkoztak a lucerna táblák közelében.

1976.05.16. $1 \mathrm{pd}$

Irénmajor mellett villanyvezetéken ült

05.18. $1 \mathrm{pd}$ Irénmajor mellett villanyvezetéken ült

07.25. $2 \mathrm{pd}$

Jánosi legelőn, cseresznyefán

08.06. $2 \mathrm{pd}$

Lébény, Töllösi erdőben, valószínű nem ott fészkeltek

1986.06.29. $1 \mathrm{pd}$ Levél község közelében, a vasút melletti erdősávban 08.21. $2 \mathrm{pd}$

1987.06.24. $2 \mathrm{pd}$ Jánossomorja, Kendergyár mellett, villanyvezetéken ültek 07.22. $3 \mathrm{pd}$ Levél közelében, fasor és közút közötti vezetéken ültek Csorna város északi határában egy nagyobb nyárfa oldalágán lévő fészeknél

1988.06.05. 3 lakott fészket találtam a Mosonszolnok és Levél közötti erdősávokban

1989.06.04. $6 \mathrm{pd}$ Mosonszolnoknál, vasút melletti erdősávban láttam 06.18. $\quad 4 \mathrm{pd}$ Mosonszolnoknál, vasút melletti erdősávban láttam 06.21. $2 \mathrm{pd}$ Mosonszolnoknál, vasút melletti erdősávban láttam 06.25. $4 \mathrm{pd}$ Mosonszolnoknál, vasút melletti erdősávban láttam 08.19. $2 \mathrm{pd}$ Jánossomorja, Kápolnatanya közelében, villanyvezetéken ültek

\section{ERDEI SZÜRKEBEGY (Prunella modularis)}

A szakirodalom csak szigetközi előfordulásról írt, hansági előfordulása és téli megjelenése érdekességnek tünt.
1975.03.22. $2 \mathrm{pd}$
Krisztinaberek, Dombosházi öregerdő
1985.05.17. $1 \mathrm{pd}$ Hanság, Nagyerdő (gyürüzve lett)
1987.01.18. $1 \mathrm{pd}$
Jánossomorja, udvaromban a madáretetőnél
1987.04.05. $1 \mathrm{pd}$
Hanság, Nagyerdőn (az 1985-ben gyürüzött visszafogása ugyanott)
1990.03.28. $1 \mathrm{pd}$
Jánossomorja, udvaromban a madáretetőnél. 